Canadian University Music Review

Revue de musique des universités canadiennes

\title{
Jeremy Tambling. Opera and the Culture of Fascism, Oxford: Clarendon Press; New York: Oxford University Press, 1996. x, 274 pp. ISBN 0-19-816566-8 (hardcover)
}

\section{Mary S. Woodside}

Volume 19, numéro 1, 1998

URI : https://id.erudit.org/iderudit/1014620ar

DOI : https://doi.org/10.7202/1014620ar

Aller au sommaire du numéro

Éditeur(s)

Canadian University Music Society / Société de musique des universités canadiennes

ISSN

0710-0353 (imprimé)

2291-2436 (numérique)

Découvrir la revue

Citer ce compte rendu

Woodside, M. S. (1998). Compte rendu de [Jeremy Tambling. Opera and the Culture of Fascism, Oxford: Clarendon Press; New York: Oxford University Press, 1996. x, 274 pp. ISBN 0-19-816566-8 (hardcover)]. Canadian University Music Review / Revue de musique des universités canadiennes, 19(1), 121-125. https://doi.org/10.7202/1014620ar

All Rights Reserved (C) Canadian University Music Society / Société de musique des universités canadiennes, 1998
Ce document est protégé par la loi sur le droit d'auteur. L'utilisation des services d'Érudit (y compris la reproduction) est assujettie à sa politique d'utilisation que vous pouvez consulter en ligne.

https://apropos.erudit.org/fr/usagers/politique-dutilisation/ 
ernist construct of the bourgeois individual subject" (p. 267), when it could easily be argued that the spectator/listener, as a subject in these interactive media, is even more of an auteur than before. There are a number of observations in the first two chapters about the origins of film music (Greek theatre, melodrama, opera) and its various aesthetic and narrative functions which have been more than adequately discussed previously, in Claudia Gorbman's Unheard Melodies (London: BFI Publishers, 1987).

Nevertheless, Overtones and Undertones remains a very useful reference on a number of levels. The book concludes with interviews with eight film composers, including Miklós Rózsa, David Raksin, Bernard Herrmann, and Henry Mancini. This is followed by a pedagogically useful outline entitled "How to hear a movie," which is broken into different aspects of film music that students can focus on: styles, generic and narrative functions, extra-filmic or contextual considerations. The third chapter on the history of film music includes some original information, and the sixth chapter is an excellent analysis of Herrmann's musical style, even though Graham Bruce's booklength study of Herrmann's music covered the topic in a satisfactory fashion (Bernard Herrmann: Film Music and Narrative [Ann Arbor, Mich.: UMI Research Press, 1985]).

In some ways, Brown's study is a happy compromise between Gorbman's Unheard Melodies and Roy Prendergast's Film Music: A Neglected Art (New York: Norton, 1977). It is a more scholarly text than Prendergast's, but does not open new theoretical avenues that Gorbman did not deal with ten years previously. On the other hand, there is a wealth of historical and musical observations that demonstrate Brown's competence as a musician and his knowledge of film and film music in particular.

Philippe Mather

Jeremy Tambling. Opera and the Culture of Fascism. Oxford: Clarendon Press; New York: Oxford University Press, 1996. x, 274 pp. ISBN 0-19816566-8 (hardcover).

The aim of this book is to show how opera was part of the culture which led to the fascist regimes of the twentieth century. Its author, a professor of comparative literature, wishes to "take opera out of the hermetically sealed state in which it is normally discussed." He warns his reader that:

Opera is a weave of voices, a dialogue between text, music, and performance, and a mixed genre ... but it also has its political unconscious because of the dominant and the marginal discourses that emerge through each opera, which do not reduce to the pairing of music and libretto ... But in wishing to go beyond treating everything extraneous to the opera as mere "background," this book will tax the patience of those who "only" like opera. ... Musicians who prefer the formalist approach to opera analysis may reflect on the consequent marginalization of music and opera from the writing of cultural history (pp. 8-9). 
The reader should also know that this is primarily a contribution to librettology and that although opera is a "dialogue between text, music and performance," the musical component of that combination is hardly mentioned. Thus, it can scarcely claim to be an antidote to the marginalization of that art from the writing of cultural history, even if it were still true that opera is generally discussed in an "hermetically sealed" state. Nonetheless, this book presents an interesting tour of the fascist and proto-fascist discourse that informs selected operas of Wagner, Verdi, Puccini, and Strauss. For it is the author's belief that

a starting point for the history of fascism entails reading much of the nineteenth century as the primeval landscape of fascism, or proto-fascism ... The phrase "the culture of fascism" has its pay-off in not isolating 1922-45 or 1933-45 as separate periods in Italian or German history (pp. 1-2).

After the introduction, the book is organized into three parts. Part I, "Opera beyond Good and Evil,"deals with Wagner; Part II, "The Modernization of Italian Opera," treats Verdi and Puccini; and Part III, "Opera, Gender, and Degeneracy," centres on the "degenerates" Richard Strauss and Franz Schreker, and, by way of conclusion, on the critique of opera contained in the works of Kurt Weill and Bertolt Brecht. Very little of the discussion is concerned with the relationship of the opera composers or librettists with actual political figures, parties, actions, or regimes. Rather, it seeks to show how culture in general "may produce fascism, or be fascist itself, and also that fascism may produce culture: a culture which cannot simply be wished away because it contains fascist elements" (p. 3). In the process, the author taps into a vast literature on fascism itself, modernism, Wagnerism, nineteenth- and twentiethcentury political philosophy and psychoanalysis, as well as opera and literary criticism.

Central to Tambling's thought is his, and our, concept of fascism. This is a word that has acquired a host of meanings outside the narrowly political. In his book Interpretations of Fascism (one of many cited by Tambling), Renzo de Felice discusses definitions used by political observers, philosophers, and social scientists of various stripes, as well as those found in the propaganda of its opponents. He points out what we all know:

At the end of World War II, with the elimination of the German and Italian Fascist regimes, movements, and parties, as well as those that had emerged during the war in all parts of Europe occupied by Axis forces, the term "Fascist" came to be employed in an increasingly indiscriminate and generic manner. It was used to characterize [certain political regimes in other parts of Europe, South America, Asia, and Africa]. Finally, and on an even more general level, the extreme Left and certain radical groups have used the adjective in an increasingly broad, indiscriminate, and distorting sense. ${ }^{1}$

1 Renzo de Felice, Interpretations of Fascism (Cambridge: Harvard University Press, 1977), 8. 
Today, "fascist" is used as a general term of opprobrium at all levels of social discourse.

It would seem essential, then, for any author to define carefully what is meant by a term so obviously open to multiple interpretations, but Tambling's method is not so straightforward. Instead, he frequently works by association, by mapping of images from diverse sources onto one another, by allusion, so that the reader gains a full image of his meaning only by a sort of osmosis or cumulative effect. For this reason, a wide knowledge of musical, philosophical, and political writing is essential to a critical reading of this book. This procedure also means that new features and definitions of the central concept can arise at any point during the discussion, especially in the words of various writers quoted. In short, the concept of fascism is built slowly over the course of the book.

We already have seen that Tambling takes a broad view of the subject, including in his purview both fascist and proto-fascist culture. Presumably, any detail of Italian or German thought or literature before 1922 or 1933 can be part of the impulse toward the twentieth-century political regime. Judging from the writers he cites, it can involve the concept of race (p. 18) and a hero who is not constrained by representative democracy, but rather who imposes order powerfully (p. 19). "Fascism rejects the Enlightenment and liberal bourgeois 'rational' values, in favour of an appeal to national unity which is under threat" (p. 23). But fascism is also ambiguous, "reactionary and revolutionary at once, modern and anti-modern together." It is modern (itself an ambiguous term), shameless, and decadent (p. 24). "Behind all this, or helping to construct it, is a gender politics" (p. 25). [The librettist D'Annunzio's] cult of masculinity ... is of the very essence of the culture of fascism" (p. 26). But "fascism also has a structure to be read psychoanalytically" (p. 28); works by authors from Erich Fromm to Julia Kristeva on the authoritarian personality, on shame, disgust, and envy all add to the portrait of the fascist mind.

Tambling is speaking for himself when he concludes his introduction, and even here he alludes to fascism only indirectly, as though there is general agreement about its essence:

A psychic structure which tends towards the authoritarian, to the imposition of rigid boundaries round the self, and a delineation of the subject, at a moment of gender, economic, and political crisis, ultimately takes on specifically Fascist forms ... My argument, in brief, is this: if we want to understand modernity, then, as Nietzsche said, we must understand Wagnerism, and to see that one strong aspect of modernity is itself fascist is something we can now understand better than Nietzsche could (p. 30).

This statement of purpose suggests that this book is centred on Wagner, but, in fact, it allots more space to Italian composers and to twentieth-century German opera. Here I shall discuss an example from Italian opera, in part because this ground has been discussed much less in connection with fascism than has Wagner. 
Part II begins with "Verdi and Imperialism: Otello." Verdi is cited as an example of a composer who "bears little relationship to any proto-fascism" but his opera nonetheless must be considered because "[i]t opens up questions of what is not consciously registered in discourse, what could not be recognized till much later" (p. 74). Thus, "Criticism of Otello (1887) and Falstaff (1893) requires going beyond the intentions of the writer and the work" (p. 73). To Tambling, the use of a number opera in the late nineteenth-century is perhaps a sign that "Verdian operas, unlike Wagner [sic], hardly recognize an unconscious and therefore the existence of repression, [and so] they may be themselves more repressed, less modern" (p. 75). As for Otello, it has at core "the representation of the 'other' of the European: the black," and this in turn is mapped onto Italy's imperialist ventures in Ethiopia. Along with Aida, the opera is therefore an operatic statement about Italian imperialism in the 1880s and this in turn shows that "fascism was not just a parenthesis in Italian history" (p. 80).

Imperialism, then, is fascist. Here we come to the weakness in this procedure; if imperialism is fascism, then this latter term is so general as to be almost meaningless and certainly not be restricted to discussions of Italy and Germany. In that case, why choose those two nations (and their composers) out of all those who have acted in a colonial (fascist) manner? Why are they the ones that can safely be castigated for the same behaviour as France, England, Russia (both Tsarist and Soviet), and the United States?

One is reminded of the portrayals of the "authoritarian personality," claimed to be the product of the German culture, subsequently blown to bits by psychological experiments that proved American individuals just as susceptible to following orders slavishly. Suddenly we see why many political observers choose to restrict the term fascist to Italy and Germany in a particular historical period only, and describe its characteristics in a very precise way. To return to Felice:

To understand the true Fascisms historically, particularly the Italian and German forms, and to distinguish them from other movements, parties, or regimes that were superficially Fascist or were not Fascist at all ... one must keep in mind the relation between the middle classes and Fascism. If not, it is difficult to appreciate the novelty and differences inherent in Fascism with respect to the conservative and authoritarian movements that preceded, accompanied, or followed it. It also precludes the possibility of understanding the origins and characteristics of Fascism and the consensus it achieved in Italy and Germany (p. 180).

In my opinion, Tambling has come perilously close to labelling everything he dislikes fascist, and in doing so falls into the difficulty Felice names.

Where Tambling's method does succeed admirably is in his mapping of opera onto the contemporary political life of Italy, seen in itself rather than necessarily as a prelude to Mussolini. Equally successful, when presented in detail at the "local" level, is the treatment of gender politics in the German operas, revealing the incredibly misogynist "patriarchal fear" of the dissolution 
of male/female hierarchies. In this, Opera and the Culture of Fascism joins other recent publications which embed opera in the discourses of their day. But it is a danger of historical writing in general, and perhaps especially of cultural history, that we go "to hunt for the present in the past." 2 Whether or not he intended to do so, Tambling gives the impression of hunting for the seeds of fascism in the nineteenth century with the goal of establishing how it came to fruition in the twentieth century and is with us yet, as though fascism were an infectious disease which has been handed from one generation to the next, and against which we must guard. The shock value comes from the realization that some of our most revered artists were "infected," perhaps even caused the disease. We need to be reminded that "it is nothing less than the whole of the past ... that produced the whole of the complex present" and that includes movements and ideas of which we ourselves approve as well as abhor. ${ }^{3}$ Nonetheless, Opera and the Culture of Fascism should be read (with a critical eye) by all who are interested in opera; we can thank Tambling for ensuring that opera librettos, at least, will not be marginalized from the writing of cultural history.

This is a handsome book, with well-chosen dust cover illustration pertinent to the text, attractive layout, and convenient documentation, including a useful bibliography (pp. 249-67) and index. A couple of errors have slipped past the editorial eye: Cambridge Music [recte Opera] Journal (p. 82 n.) and Un Ballo in Blaschera [recte Maschera] (p. 110).

Mary S. Woodside

Lawrence Kramer. After the Lovedeath: Sexual Violence and the Making of Culture. Berkeley and Los Angeles: University of California Press, 1997. ix, $281 \mathrm{pp}$. ISBN 0-520-21012-3 (hardcover).

In Tolstoy's story, "The Kreutzer Sonata," a jealous man named Pozdnyshev murders his wife because he suspects her of infidelity. He grounds his suspicions in the fact that his wife plays Beethoven's famous sonata with a downat-heels violinist named Trukhachevski. When Pozdnyshev catches sight of the violinist and pianist together, leaning over the piano examining a score-even when he hears their voices intermingling in conversation, or eavesdrops on their rehearsals of Beethoven-he surmises that they are betraying him. The sonata expresses, synecdochically, this adultery, however fictitious it may be. Moreover, Pozdnyshev promotes their infidelity. When his wife offers to cancel a planned concert, Pozdnyshev threatens her. As Lawrence Kramer argues, "[t]o become a cuckold may well be Pozdnyshev's strongest sexual desire" (p. 209). Unable to control the desires of his wife, embodied in sonata structure (theme, development, return) and in sound itself, Pozdnyshev stabs her with a dagger. Trukhachevski, on the other hand, escapes the wrath of the jealous husband by ducking under the piano and hightailing it out the door. The

2 Herbert Butterfield, The Whig Interpretation of History (London, G. Bell and Sons, 1963), 10. 3 Ibid., 19. 